\title{
Karakteristik Dendeng Lambok Khas Sumatera Barat dengan Metode Pengolahan dan Lama Penyimpanan yang Berbeda
}

\author{
Bunga Putri Febrina ${ }^{1 *}$, Tuti Suryati ${ }^{2 *}$, Irma Isnafia Arief ${ }^{2}$ \\ ${ }^{1}$ Program Studi Ilmu Produksi dan Teknologi Peternakan, Fakultas Peternakan, Sekolah \\ Pascasarjana Institut Pertanian Bogor \\ ${ }^{2}$ Departemen Ilmu Produksi dan Teknologi Peternakan, Fakultas Peternakan IPB \\ Jl. Agatis Kampus IPB Darmaga, Bogor 16680 \\ *Email korespondensi: bungaputrifebrina08@gmail.com, tutisuryati16@gmail.com
}

(Diterima: 20-12-2018; disetujui 10-1-2019)

\begin{abstract}
ABSTRAK
Dendeng merupakan salah satu hasil pengolahan daging yang digemari masyarakat Indonesia. Salah satunya di Sumatera Barat terdapat dendeng yang dimodifikasi yakni dendeng lambok batokok. Tujuan penelitian ini untuk menganalis metode pengolahan yang tepat untuk menghambat proses oksidasi lemak dan kerusakan mikrobiologi pada suhu ruang, sehingga menghasilkan dendeng lambok yang berkualitas dan aman dikonsumsi. Variabel yang diamati meliputi sifat fisik (Kadar air, aktivitas air dan $\mathrm{pH}$ ), sifat kimia (kandungan malonaldehida, antioksidan) dan analisis pertumbuhan mikroba (total plate count, S.aureus, E.coli, dan Salmonella). Rancangan penelitian yang digunakan adalah rancangan acak kelompok pola faktorial, dengan faktor pertama adalah metode pengolahan meliputi penggorengan dan pemanggangan, dan faktor kedua adalah waktu penyimpanan meliputi 0,2,4,dan 6 hari. Hasil penelitian menunjukkan bahwa metode pengolahan memberikan pengaruh yang nyata $(\mathrm{P}<0,05)$ kecuali $\mathrm{pH}$. Lama penyimpanan berpengaruh nyata $(\mathrm{P}>0,05)$ kecuali $\mathrm{pH}$ dan kadar air. Hasil analisis mikrobiologi menunjukkan interaksi antara metode pengolahan dan lama penyimpanan. Berdasarkan penelitian ini, dendeng lambok batokok dengan metode pengolahan digoreng memiliki kadar air, aktivitas air dan $\mathrm{pH}$ yang lebih rendah, serta MDA dan aktioksidan yang lebih tinggi dibandingkan yang dipanggang. Dilihat dari segi mikrobiologi dendeng lambok masih aman dikonsumsi sampai hari kedua penyimpanan suhu ruang.
\end{abstract}

Kata kunci: dendeng lambok, pengolahan, penyimpanan, fisikokimia, mikrobiologi

\begin{abstract}
Dendeng is one of meat processing product preferred by Indonesian. One of them in West Sumatra, there is a modified dendeng namely dendeng lambok batokok. The purpose of this study was to analyze the appropriate processing methods to inhibit the process of fat oxidation and microbiological damage at room temperature, so as to produce high-quality dendeng lambok and safe for consumption. The variables observed included physical properties (moisture content, water activity, and $\mathrm{pH}$ ), chemical properties (malonaldehyde content, antioxidants) and microbial growth analysis (total plate count, $S$. aureus, E. coli, and Salmonella). The study design used was a factorial randomized block design, with the first factor was the processing method including frying and roasting, and the second factor was the storage time including 0,2,4 and 6 days. The results showed that the processing method had a significant effect $(\mathrm{P}<0,05)$ except on $\mathrm{pH}$. Storage duration had a significant effect $(\mathrm{P}>0,05)$ except on $\mathrm{pH}$ and water content. The results of the microbiological analysis showed that there was an interaction between processing methods and storage time. Based on this study, dendeng lambok batokok with frying process has lower water content, water activity and $\mathrm{pH}$, and higher MDA and antioxidants than the roasting process. In terms of microbiology, dendeng lambok is still safe to consume until the second day of storage at room temperature.
\end{abstract}

Keywords: dendeng lambok, processing, storage, physicochemical, microbiology 


\section{PENDAHULUAN}

Daging sapi merupakan bahan pangan yang mengandung gizi yang dibutuhkan oleh tubuh manusia untuk pertumbuhan dan kesehatan (Arifin et al. 2008). Bahan pangan asal ternak ini mengandung nutrisi berupa air, protein, lemak, mineral, dan sedikit karbohidrat sehingga dengan kandungan tersebut menjadikannya media yang baik untuk pertumbuhan bakteri dan mudah mengalami kerusakan (Nurwantoro et al. 2012), oleh karena itu diperlukan metode pengolahan yang tepat sebagai salah satu cara untuk mengurangi kerusakan daging sekaligus memperoleh nilai tambah dari produk yang dihasilkan (Rasyad et al. 2012). Salah satu produk hasil olahan dan pengaweten daging sapi yang sudah dilakukan yaitu dendeng. Dendeng merupakan makanan tradisional Indonesia yang berbentuk lempengan terbuat dari irisan atau gilingan daging segar yang telah diberi bumbu dan dikeringkan SNI 2908 (2013). Daerah Sumatera barat memiliki modifikasi dendeng yaitu dendeng lambok batokok. Lambok dalam bahasa minang artinya lembab sedangkan batokok artinya dipukul, sehingga dendeng lambok batokok adalah dendeng basah yang dibuat dengan cara merebus daging dengan bumbu-bumbu kemudian dipukul-pukul dan dilakukan penggorengan atau pemanggangan (Marzaleni, 2005). Proses pengolahan seperti pemanggangan maupun penggorengan serta penyimpanan akan berpotensi menimbulkan reaksi oksidasi lemak yang menyebabkan turunnya nilai gizi dan rusaknya cita rasa produk yang dihasilkan (Saghir et al., 2005). Faktor yang mempengaruhi terjadinya oksidasi antara lain kadar air, $\mathrm{a}_{\mathrm{w}}$ dan suhu (Flick et al.1992). Pencegahan oksidasi pada dendeng dapat dilakukan dengan penambahan antioksidan yang terdapat dalam bumbu-bumbu yang digunakan diantaranya bawang putih, jahe dan air kelapa. Metode pengolahan dendeng lambok batokok perlu diperhatikan, sehingga aman di konsumsi. Berdasarkan uraian diatas maka dilakukan penelitian dengan metode pengolahan yang tepat untuk menghambat proses oksidasi lemak dan kerusakan mikrobiologi sehingga menghasilkan dendeng lambok yang berkualitas dengan daya simpan yang lebih lama.

\section{METODE PENELITIAN}

\section{Materi Penelitian}

Bahan-bahan yang digunakan yaitu daging sapi bagian paha belakang sebanyak $7000 \mathrm{~g}$ yang dibeli dari PT Elders Indonesia. Bumbu-bumbu diperoleh dari Agroslestari. Bahan-bahan kimia yang digunakan antara lain propil galat $(\mathrm{PG})$ etilendiamintetraasetat (EDTA), larutan 1,1,3,3tetraetioksipropan (TEP), larutan thiobarbituric acid (TBA), metanol, 1,1-difenil 2 pikrilhidrazil (DPPH), dan larutan vitamin $\mathrm{C}$, buffer pepton water (BPW), xylose lysine desoxycholate agar (XLDA), eosyn methylen blue agar (EMBA), baird parker agar (BPA), plate count agar (PCA).

Alat-alat yang digunakan dalam penelitian ini adalah $\mathrm{pH}$ meter, $\mathrm{a}_{\mathrm{w}}$ meter, timbangan digital, oven, erlenmeyer, colony counter, pembakar bunsen, pengocok tabung (vortex), inkubator, magnetic stirrer, laminar, slicer, food processor, waterbath, dan spektrofotometer.

\section{Metode Penelitian}

Pembuatan dendeng. Dendeng dibuat dengan menggunakan bumbu-bumbu yang terdiri dari bawang putih, lengkuas, jahe, kunyit, ketumbar, garam, air kelapa dan minyak kelapa, jumlahnya dapat dilihat pada Tabel 1. Daging yang digunakan adalah paha belakang (silver side), kemudian diiris tipis ukuran $8 \times 8 \times 0.5 \mathrm{~cm}$ menggunakan slicer daging. Bumbu-bumbu yang telah dihaluskan dicampurkan dengan daging dan dilakukan pemeraman selama 2 jam. Kemudian dilakukan perebusan mengunakan air kelapa selama 45 menit dan setelah itu daging dipukul menggunakan palu kayu. Setelah itu dilakukan penggorengan dan pemanggangan serta dikemas menggunakan plastik vacum.

Tabel 1. Bumbu-Bumbu yang Digunakan

\begin{tabular}{cc}
\hline Jenis bahan & Komposisi* \\
\hline Daging sapi & $1000 \mathrm{~g}$ \\
Bawang putih & $65 \mathrm{~g}$ \\
Lengkuas & $30 \mathrm{~g}$ \\
Jahe & $12 \mathrm{~g}$ \\
Kunyit & $6.26 \mathrm{~g}$ \\
Ketumbar & $1.50 \mathrm{~g}$ \\
Garam & $15 \mathrm{~g}$ \\
Minyak & Minyak sawit \\
Air kelapa & $200 \mathrm{~mL}$ \\
\hline
\end{tabular}

${ }^{*}$ komposisi berdasarkan trial and error

Analisis Fisik Dendeng Lambok. Aktivitas air $\left(\alpha_{\mathrm{w}}\right)$ diukur dengan menggunakan aw meter Novasina ms1 Set-aw (Swiss) (Novasiana 2010). Pengukuran $\mathrm{pH}$ menggunakan alat $\mathrm{pH}$ daging (AOAC, 2005). Kadar Air menggunakan metode (AOAC, 2005).

Analisis Kandungan Malonaldehida (MDA). Pengujian kadar MDA yang dinyatakan sebagai bilangan TBARS (thiobarbituric acid 
reactive substances) dilakukan dengan metode destilasi mengikuti prosedur Sorensen dan Jorgensen (1996). Penentuan TBARS dilakukan dengan menggunakan spektrofotometer pada 532 nm.

\section{Analisis Aktivitas Antioksidan.}

Pengujian dilakukan dengan menggunakan metode yang digunakan oleh Tangkanakul et al. (2009). Ekstraksi Sampel. Sampel diekstraksi menggunakan $100 \%$ metanol pada suhu ruang. Aktivitas Scavenging Radikal DPPH. Sebanyak $0.15 \mathrm{~mL}$ ekstrak sampel ditambahkan dengan 0.9 $\mathrm{mL}$ larutan metanolat DPPH $0.1 \mathrm{mM}$. Ekstrak diinkubasi selama 30 menit pada suhu $37^{\circ} \mathrm{C}$ Setelah 30 menit, absorbansi campuran diukur pada panjang gelombang $517 \mathrm{~nm}$. Metanol murni digunakan sebagai kontrol. Kapasitas Antioksidan. Kapasitas antioksidan ditentukan berdasarkan kemampuan ekstrak dendeng dalam meredam radikal bebas DPPH dibandingkan terhadap antioksidan.

Analisis Mikroba. Analisis total plate count (TPC) menggunakan metode BAM (2016), analisis Staphylococcus aureus menggunakan metode SNI (2013), Escheria coli menggunakan metode SNI (2013) dan Salmonella $s p$ menggunakan metode BAM (2016).

\section{Analisis Statistik}

Penelitian ini dirancang dengan menggunakan desain rancangan acak kelompok pola faktorial (RAKF) 2 x 4 dengan 3 (tiga) ulangan. Faktor pertama adalah metode pemasakan (metode penggorengan dan metode pemanggangan). Faktor kedua adalah waktu penyimpanan $(0,2,4$, dan 6 hari pada suhu ruang). Pembagian kelompok berdasarkan waktu pembuatan yang berbeda (Steel \& Torrie 1995). Data yang diperoleh dianalisis dengan analisis ragam. Apabila terdapat perbedaan antar perlakuan, dilakukan uji Least Squares Means. Pengolahan data dilakukan dengan menggunakan program SAS 9.0.

\section{HASIL DAN PEMBAHASAN}

\section{Kadar air}

Hasil penelitian ini menunjukkan bahwa kadar air pada dendeng lambok tidak ada interaksi antara metode pemasakan dengan lama penyimpanan. Namun demikian kadar air nyata dipengaruhi oleh metode pemasakan $(\mathrm{P}<0,05)$. Kadar air dendeng lambok yang digoreng lebih rendah dibandingkan dengan dipanggang. Hal ini disebabkan oleh metode penggorengan yang mengunakan suhu yang tinggi sehingga menghasilkan dendeng yang lebih kering dibandingkan yang dipanggang. Ikhsan (2016) menyatakan bahwa tinggi rendahnya kadar air dendeng dipengaruhi oleh suhu dan lama waktu pengeringan, semakin tinggi suhu dan lama pengeringan maka kadar air akan semakin rendah. Purnomo (1997) menyatakan kadar air produk dendeng mempunyai kadar air pada kisaran $20-40 \%$. Tingginya Kadar air dendeng lambok dari penelitian disebabkan pembuatan dendeng lambok masih dilakukan secara tradisional dan skala rumah tangga yang dagingnya memiliki tekstur basah.

Tabel 2 Kadar air dendeng lambok selama penyimpanan (\% BB)

\begin{tabular}{|c|c|c|c|c|c|}
\hline \multirow{2}{*}{$\begin{array}{l}\text { Metode } \\
\text { pemasakan }\end{array}$} & \multicolumn{4}{|c|}{ Lama penyimpanan hari ke- } & \multirow{2}{*}{ Rataan } \\
\hline & 0 & 2 & 4 & 6 & \\
\hline Goreng & $24,26 \pm 2,92$ & $26,47 \pm 4,82$ & $20,07 \pm 1,13$ & $26,08 \pm 3,27$ & $22,72 \pm 3,04^{b}$ \\
\hline Panggang & $41,07 \pm 2,50$ & $46,61 \pm 2,51$ & $44,16 \pm 3,33$ & $44,15 \pm 1,94$ & $44,00 \pm 2,57^{\mathrm{a}}$ \\
\hline Rataan & $32,67 \pm 2,71$ & $36,54 \pm 3,67$ & $32,12 \pm 2,23$ & $32,11 \pm 2,60$ & \\
\hline
\end{tabular}

Angka-angka pada kolom atau baris yang sama dan diikuti huruf berbeda menunjukkan berbeda nyata $(\mathrm{P}<0,05)$

\section{Aktivitas Air}

Nilai aktivitas air pada penelitian ini disajikan pada Tabel 3. Aktivitas air $\left(\mathrm{a}_{\mathrm{w}}\right)$ dendeng nyata dipengaruhi $(\mathrm{P}<0,05)$ oleh lama penyimpanan dan metode pemasakan namun tidak ada interaksi diantara keduanya. Nilai $\mathrm{a}_{\mathrm{w}}$ yang diperoleh pada penelitian ini berkisar 0.79 0.86 . Dendeng yang beredar di pasaran pada umumnya memiliki $a_{w}$ 0,40-0,50 (Purnomo 1997). Tingginya nilai $a_{w}$ dendeng lambok batokok disebabkan pada proses pembuatan dendeng lambok tidak melakukan pengeringan seperti halnya dendeng lainnya. Metode pemasakan dendeng yang di panggang memiliki $\mathrm{a}_{\mathrm{w}}$ yang lebih tinggi dibandingkan yang dipanggang karena suhu dan kelembaban yang tidak dapat dikontrol. Suharyanto (2009) menyatakan bahwa hubungan antara $a_{w}$ dan kelembaban adalah hubungan kesetimbangan antara kadar air di udara bila kadar air tinggi 
makan akan menyerap air dan sebaliknya sehingga dicapai kesetimbangan. Peningkatan $\mathrm{a}_{\mathrm{w}}$ selama penyimpanan disebabkan oleh degradasi molekul-molekul pada bahan oleh mikroorganisme berupa pelepasan air terikat yang mengakibatkan terbentuknya air bebas. Namun demikian $\mathrm{a}_{\mathrm{w}}$ ini masih termasuk dalam kisaran $\mathrm{a}_{\mathrm{w}}$ bahan pangan semi basah, yaitu 0,60-0,92. Menurut Salguero et al. (1994) bahan pangan semi basah memiliki $a_{w}$ antara 0,60-0,91 dan menurut Purnomo (1997) bahwa dendeng memiliki $a_{w} 0,60-0,80$.

Tabel 3 Aktivitas air dendeng lambok selama penyimpanan

\begin{tabular}{|c|c|c|c|c|c|}
\hline \multirow{2}{*}{$\begin{array}{l}\text { Metode } \\
\text { pemasakan }\end{array}$} & \multicolumn{4}{|c|}{ Lama Penyimpanan Hari ke- } & \multirow[b]{2}{*}{ Rataan } \\
\hline & 0 & 2 & 4 & 6 & \\
\hline \multirow{3}{*}{$\begin{array}{l}\text { Goreng } \\
\text { panggang } \\
\text { Rataan }\end{array}$} & $0,79 \pm 0,03$ & $0,84 \pm 0,02$ & $0,82 \pm 0,03$ & $0,81 \pm 0,02$ & $0,81 \pm 0,02^{b}$ \\
\hline & $0,81 \pm 0,01$ & $0,84 \pm 0,00$ & $0,84 \pm 0,01$ & $0,86 \pm 0,01$ & $0,84 \pm 0,02^{\mathrm{a}}$ \\
\hline & $0,80 \pm 0,02 b$ & $0,84 \pm 0,01^{\mathrm{a}}$ & $0,83 \pm 0,01^{\mathrm{a}}$ & $0,84 \pm 0,03^{\mathrm{a}}$ & \\
\hline
\end{tabular}

Angka-angka pada kolom atau baris yang sama dan diikuti huruf berbeda menunjukkan berbeda nyata $(\mathrm{P}<0,05)$

\section{Nilai pH}

Penelitian ini menunjukkan nilai $\mathrm{pH}$ dendeng lambok selama penyimpanan tidak menunjukkan pengaruh yang nyata (Tabel 4). Hal ini disebabkan oleh $\mathrm{pH}$ awal daging mentah yang relatif sama dengan dendeng yang sudah digoreng maupun dipanggang. Nilai $\mathrm{pH}$ daging sesudah disembelih berkisar $6,7-8$ tetapi dalam waktu 25 jam sesudah dipotong terjadi penurunan pH hingga 5,6-5,8 didalam semua otot-otot (Resang 1982). Terjadinya penurunan $\mathrm{pH}$ selama penyimpanan diduga disebabkan oleh kerja enzim yang belum maksimal, menyebabkan kurang mampunya menghidrolisa protein dalam daging. Menurut Afrila (2012) jumlah enzim proteolitik yang dalam jumlah sedikit kurang mampu menghidrolisa protein sehingga mengakibatkan penurunan $\mathrm{pH}$. Berdasarkan penelitian Suryati et al. (2012) $\mathrm{pH}$ dendeng komersil yang digoreng menunjukkan nilai $\mathrm{pH}$ 5,19-5,90 hal tersebut tidak dipengaruhi oleh metode pemasakan, namun disebabkan penggunaan bumbu yang digunakan. Dari penelitian ini, nilai $\mathrm{pH}$ yang diperoleh sudah memenuhi nilai $\mathrm{pH}$ dendeng komersil dan skala industri.

Tabel 4 Nilai $\mathrm{pH}$ dendeng lambok selama penyimpanan

\begin{tabular}{|c|c|c|c|c|c|}
\hline \multirow{2}{*}{$\begin{array}{l}\text { Metode } \\
\text { pemasakan }\end{array}$} & \multicolumn{4}{|c|}{ Lama Penyimpanan Hari ke- } & \multirow{2}{*}{ Rataan } \\
\hline & 0 & 2 & 4 & 6 & \\
\hline Goreng & $5,74 \pm 0,23$ & $5,74 \pm 0,10$ & $5,69 \pm 0,16$ & $5,74 \pm 0,17$ & $5,73 \pm 0,03$ \\
\hline Panggang & $5,89 \pm 0,23$ & $5,72 \pm 0,28$ & $5,71 \pm 0,17$ & $5,82 \pm 0,04$ & $5,79 \pm 0,09$ \\
\hline Rataan & $5,82 \pm 0,10$ & $5,72 \pm 0,01$ & $5,71 \pm 0,02$ & $5,82 \pm 0,06$ & \\
\hline
\end{tabular}

Angka-angka pada kolom yang sama dan diikuti huruf berbeda menunjukkan berbeda nyata $(\mathrm{P}<0,05)$

\section{Hasil Analisis TPC}

Pada Tabel 5. dapat dilihat analis total plate count (TPC) menunjukkan adanya interaksi antara metode pemasakan dan lama penyimpanan $(\mathrm{P}<0,05)$. Hal ini diduga disebabkan oleh kadar air yang terkandung dalam dendeng lambok. Menurut Winarno (2008) seluruh makhluk hidup membutuhkan air untuk pertumbuhan dan perkembangan. Aminudin (2009) menyatakan pertumbuhan bakteri atau mikroba pada makanan yang diolah dipengaruhi oleh kadar air dan makanan yang mengandung protein dibutuhkan oleh bakteri untuk hidup dan berkembang biak. Soeparno (2005) menyatakan bahwa bumbu dan garam yang ditambahkan dalam produk memliki fungsi sebagai pengawet yang dapat menghambat pertumbuhan mikroba. Menurut SNI (2009) jumlah TPC maksimal dendeng adalah 5 log $\mathrm{CFU} / \mathrm{g}$ pada penelitian ini dari segi TPC masih layak di konsumsi.

\section{Hasil Analisis Bakteri Staphylococcus aureus}

Hasil analisis bakteri $S$. aureus dapat dilihat pada Tabel 5. Hasilnya menunjukkan terdapat interaksi antara metode pemasakan dan lama penyimpanan dendeng lambok $(\mathrm{P}<0,05)$. Total bakteri $\mathrm{S}$. aureus mengalami peningkatan selama penyimpanan baik dendeng yang digoreng maupun yang dipanggang. Hal ini diduga karena faktor suhu, aktivitas air dan kadar air selama penyimpanan. Menurut Jahidin (2014) yang menyebabkan tinggi rendahnya perkembangan bakteri $S$. aureus adalah nilai $\mathrm{a}_{\mathrm{w}}$, kadar air dan suhu penyimpanan. 
Tabel 5. Pertumbuhan mikroba dendeng lambok selama penyimpanan

\begin{tabular}{|c|c|c|c|c|c|}
\hline \multirow{2}{*}{$\begin{array}{l}\text { Metode } \\
\text { pemasakan }\end{array}$} & \multicolumn{4}{|c|}{ Lama Penyimpanan Hari ke- } & \multirow{2}{*}{ Rataan } \\
\hline & 0 & 2 & 4 & 6 & \\
\hline & \multicolumn{5}{|c|}{ TPC $(\log \mathrm{CFU} / \mathrm{g})$} \\
\hline Goreng & $3,72 \pm 0,10^{\mathrm{d}}$ & $3,99 \pm 0,17^{\mathrm{c}}$ & $4,79 \pm 0,11^{\mathrm{a}}$ & $4,76 \pm 0,20^{\mathrm{a}}$ & $4,31 \pm 0,54$ \\
\hline Panggang & $3,76 \pm 0,17^{\mathrm{cd}}$ & $4,22 \pm 0,21^{b c}$ & $4,24 \pm 0,02^{b c}$ & $4,28 \pm 0,05^{\mathrm{b}}$ & $4,12 \pm 0,24$ \\
\hline Rataan & $3,74 \pm 0,03$ & $4,11 \pm 0,17$ & $4,52 \pm 0,39$ & $4,52 \pm 0,34$ & \\
\hline \multicolumn{6}{|c|}{ Total Koloni S,aureus (log CFU/g) } \\
\hline Goreng & - & - & $2,25 \pm 0,23^{b}$ & $3,54 \pm 0,30^{\mathrm{a}}$ & $1,45 \pm 1,75$ \\
\hline Panggang & - & $1,90 \pm 1,67^{\mathrm{b}}$ & $2,96 \pm 0,29^{\mathrm{ab}}$ & $3,07 \pm 0,67^{\mathrm{ab}}$ & $1,98 \pm 1,42$ \\
\hline Rataan & - & $0,95 \pm 1,34$ & $2,60 \pm 0,51$ & $3,31 \pm 0,33$ & \\
\hline
\end{tabular}

Total Koloni Escheria coli $(\log \mathrm{CFU} / \mathrm{g})$

\begin{tabular}{llllll} 
Goreng & - & - & - & - & - \\
Panggang & - & - & - & - & - \\
Rataan & - & - & - & - \\
\hline
\end{tabular}

Total Koloni Salmonella (log CFU/g)

\section{Goreng \\ Panggang \\ Rataan}

Angka-angka pada kolom atau baris yang sama dan diikuti huruf berbeda menunjukkan berbeda nyata

Pada metode pemanggangan bakteri $S$. aureus telah tumbuh pada hari ke- 2 hal ini diduga proses pemanasan yang kurang sempurna. Menurut Pelczar dan Chan (2008) organisme ini dapat berasal dari orang-orang yang menangani pangan. SNI (2013) menyatakan bahwa syarat maksimal untuk pertumbuhan $S$. aureus dalam dendeng adalah $2 \log \mathrm{CFU} / \mathrm{g}$. Penelitian ini menunjukkan bahwa pada metode pemasakan yang digoreng maupun yang dipanggang selama peyimpanan suhu ruang yang sesuai dengan SNI adalah sampai hari ke 2 yang layak konsumsi sedangkan hari ke 4 dan ke 6 sudah tidak layak konsumsi lagi.

\section{Hasil Analisis Bakteri Escheria coli}

Penelitian ini menunjukkan hasil analisis bakteri E. coli pada dendeng lambok batokok tidak terdeteksi (Tabel 5). Hal ini menunjukkan bahwa dendeng yang telah disimpan pada suhu ruang (menggunanakan plastik vacum) aman terhadap kontaminasi E.coli. Menurut SNI (2013) batas maksimum cemaran $E$. coli terhadap produk dendeng sebesar $<3 \mathrm{CFU} / \mathrm{g}$. Tidak terdeteksinya bakteri ini diduga berperannya kandungan senyawa-senyawa aktif dalam bumbu yang dapat berfungsi sebagai antimikroba serta proses pemasakan seperti pemanasan yang dapat menghilangkan bakteri ini (Thipparedi dan Sanchez 2006). Jumlah E. coli yang melebihi 2 $\log$ CFU/g menunjukkan bahwa produk yang dikonsumsi digunakan sebagai indikator kontaminasi cemaran pada status kebersihan makanan (Health Protection Agency 2009). Kontaminasi bakteri patogen dapat terjadi selama proses penanganan, pengolahan serta dari peralatan yang di gunakan (Gorris 2005).

\section{Hasil Analisis Bakteri Salmonella sp}

asil penelitian pada dendeng lambok batokok yang disimpan sampai 6 hari menunjukkan tidak terdeteksinya bakteri salmonella (Tabel 5). Hal ini disebabkan penggunaan plastik vakum sehingga menyebabkan kondisi anaerob. Poluakan et al. (2015) menyatakan Salmonella bersifat aerob dan anaerob fakultatif sehingga pengemasan vakum sangat baik digunakan, karena dapat menghambat perumbuhan salmonella dengan cara menghampakan udara dalam kemasan. Menurut SNI (2013) produk dendeng mengharuskan kandungan bakteri Salmonella negatif. Dari hasil penelitian ini didapatkan hasil untuk Salmonella negatif, dan sudah sesuai dengan standar SNI. Tidak terdeteksinya salmonella menunjukkan bahwa pengolahan yang dilakukan seperti menjaga kebersihan dan pengolahan makanan yang higienis dapat mencegah terjadinya pencemaran dari makanan (Pelchzar dan Chan 2008). 


\section{Kadar Malonaldehida}

Tabel 6 menunjukkan kadar malonaldehida (MDA) dendeng nyata dipengaruhi $(\mathrm{P}<0,05)$ oleh metode pengolahan dan lama penyimpanan serta tidak ada interaksi diantara keduanya. Dendeng yang digoreng memiliki kandungan MDA yang tinggi dibandingkan dengan yang panggang hal ini disebabkan oleh suhu penggorengan yang tinggi dan penggunaan dari minyak goreng, dibandingkan dengan yang dipanggang tanpa penggunaan minyak dan suhu pemanggangan yang tidak terlalu tinggi. Daging yang digunakan adalah daging beku sehingga mudah mengalami oksidasi yang menyebabkan kandungan MDA tinggi (Akoh 2006). Berdasarkan penelitian Okolie et al. (2013) nilai MDA daging yang direbus kemudian dilakukan penggorengan memiliki kandungan MDA senilai 4,19 mg/kg dan yang dipanggang sebesar $2,26 \mathrm{mg} / \mathrm{kg}$, hasilnya lebih tinggi dibandingkan penelitian ini.
Menurut Okolie et al. (2013) proses perebusan kemudian dilakukan penggorengan dapat meningkatkan 2 kali lebih tinggi kadar MDA dibandingkan dengan yang mentah. Dari tabel 6 dapat dilihat selama penyimpanan dendeng lambok batokok cenderung mengalami peningkatan, hal ini disebabkan oleh oksidasi lemak pada bahan pangan yang akan bereaksi secara simultan pada kondisi waktu yang berbeda (Aragao et al., 2008). Oksidasi tersebut dipengaruhi oleh bahan, alat, proses pengolahan, pengemasan, dan penyimpanan. Faktor oksidasi meliputi suhu, cahaya, $\mathrm{pH}$, dan kelembaban. Rendahnya nilai MDA dendeng lambok dibandingkan penelitian Okolie et al. (2013) diduga karena penggunaan bumbu-bumbu. Berdasarkan penelitian Suryati et al. (2014) penggunaan bumbu-bumbu dapat memberikan kontribusi sebagai senyawa antioksidan yang berperan dalam menghambat oksidasi lipid.

Tabel 6 Kadar MDA dendeng lambok selama penyimpanan suhu ruang

\begin{tabular}{|c|c|c|c|c|c|}
\hline \multirow{2}{*}{$\begin{array}{l}\text { Metode } \\
\text { pengolahan }\end{array}$} & \multicolumn{4}{|c|}{ Lama Penyimpanan Hari ke- } & \multirow{2}{*}{ Rataan } \\
\hline & 0 & 2 & & 6 & \\
\hline & & & $(\mathrm{mg} / \mathrm{kg})$ & & \\
\hline Goreng & $0,26 \pm 0,01$ & $0,72 \pm 0,11$ & $0,97 \pm 0,03$ & $0,93 \pm 0,21$ & $0,72 \pm 0,32^{\mathrm{a}}$ \\
\hline Panggang & $0,09 \pm 0,01$ & $0,32 \pm 0,08$ & $0,86 \pm 0,16$ & $0,62 \pm 0,00$ & $0,48 \pm 0,33^{\mathrm{b}}$ \\
\hline Rataan & $0,18 \pm 0,12^{b}$ & $0,52 \pm 0,28^{c}$ & $0,92 \pm 0,08^{\mathrm{a}}$ & $0,78 \pm 0,22^{\mathrm{a}}$ & \\
\hline
\end{tabular}

Angka-angka pada kolom yang sama dan diikuti huruf berbeda menunjukkan berbeda nyata $(\mathrm{P}<0,05)$.

\section{Aktivitas Antioksidan}

Tabel 7 menunjukkan aktivitas antioksidan dendeng lambok nyata dipengaruhi $(\mathrm{P}<0,05)$ oleh metode pengolahan dan lama penyimpanan serta tidak ada interaksi diantara keduanya. Metode pemasakan yang digoreng menunjukkan kapasitas antioksidan yang lebih tinggi dibandingkan dengan yang dipanggang. Hal ini diduga disebabkan oleh adanya produk reaksi mailard yang memiliki aktivitas antioksidan yaitu melanoidin (Suryati et al. 2012: Nagai et al. 2012). Aisyah et al. (2014) menyatakan bahwa metode pemasakan dapat mempengaruhi tekstur, nilai nutrisi serta kapasitas antioksidan dalam pangan. Lama penyimpanan kapasitas antioksidan berpengaruh nyata hanya pada hari ke 0 dan 2 sedangkan pada hari ke 4 serta hari ke 6 tidak menunjukkan adanya perbedaan. Penurunan kapasitas antioksidan selama penyimpanan disebabkan oleh suhu ruang yang tidak dapat dikontrol serta mudah terkena paparan sinar matahari. Dwiyanti (2014) menyatakan bahwa antioksidan akan semakin menurun selama penyimpanan karena pengaruh cahaya selama penyimpanan.

Tabel 7 Aktivitas antioksidan dendeng lambok selama penyimpanan suhu ruang

\begin{tabular}{|c|c|c|c|c|c|}
\hline \multirow{2}{*}{$\begin{array}{l}\text { Metode } \\
\text { pengolahan }\end{array}$} & \multicolumn{4}{|c|}{ Lama Penyimpanan Hari ke- } & \multirow{2}{*}{ Rataan } \\
\hline & 0 & 2 & 4 & 6 & \\
\hline & \multicolumn{5}{|c|}{ Kapasitas antioksidan (mg EVC g $\left.{ }^{-1}\right)$} \\
\hline Goreng & $88,15 \pm 1,93$ & $66,92 \pm 9,63$ & $73,68 \pm 10,20$ & $70,86 \pm 6,41$ & $74,91 \pm 9,26^{\mathrm{a}}$ \\
\hline Panggang & $85,75 \pm 16,20$ & $62,15 \pm 6,00$ & $40,54 \pm 8,40$ & $39,01 \pm 7,65$ & $56,86 \pm 21,96^{b}$ \\
\hline Rataan & $86,95 \pm 1,70^{\mathrm{a}}$ & $64,54 \pm 3,38^{b}$ & $57,11 \pm 23,43^{b}$ & $54,94 \pm 22,52^{b}$ & \\
\hline \multicolumn{6}{|c|}{ Aktivitas penghambatan DPPH (\%) } \\
\hline Goreng & $85,17 \pm 1,85$ & $62,11 \pm 12,41$ & $63,66 \pm 3,55$ & $69,72 \pm 6,87$ & $70,16 \pm 10,53^{a}$ \\
\hline Panggang & $82,38 \pm 14,83$ & $58,49 \pm 6,16$ & $40,18 \pm 6,18$ & $40,08 \pm 9,64$ & $55,29 \pm 20,03^{b}$ \\
\hline Rataan & $83,78 \pm 1,97^{\mathrm{a}}$ & $60,30 \pm 2,55^{\mathrm{b}}$ & $51,92 \pm 16,59^{b}$ & $54,90 \pm 20,95^{b}$ & \\
\hline
\end{tabular}

Angka-angka pada kolom atau baris yang sama dan diikuti huruf berbeda menunjukkan berbeda nyata $(\mathrm{P}<0,05)$. 
Tabel 7 menunjukkan kapasitas penghambatan DPPH dendeng lambok nyata dipengaruhi $(\mathrm{P}<0,05)$ oleh metode pengolahan dan lama penyimpanan serta tidak ada interaksi diantara keduanya. Metode pemasakan menunjukkan aktivitas penghambatan DPPH dendeng yang digoreng lebih tinggi dari pada yang dipanggang. Berdasarkan penelitian Suryati et al. (2014) aktivitas penghambatan DPPH berkisar 21,06\%-62,91\% sedangkan, pada penelitian ini berkisar 40,08\%-85,17\% hal tesebut terjadi diakibatkan oleh penggunaan bumbu dan jumlah yang berbeda. Tangkanakul (2009) menyatakan bahwa antioksidan dapat dipengaruhi oleh jumlah dan jenis bumbu yang digunakan.

\section{KESIMPULAN}

Dendeng lambok batokok dengan metode pengolahan digoreng memiliki kadar air, aktivitas air dan $\mathrm{pH}$ yang lebih rendah, serta MDA dan aktioksidan yang lebih tinggi dibandingkan yang dipanggang. Dilihat dari segi mikrobiologi dendeng lambok masih aman dikonsumsi sampai hari kedua penyimpanan suhu ruang.

\section{UCAPAN TERIMA KASIH}

Pihak Beasiswa Unggulan Masyarakat Berprestasi, Kementerian Pendidikan dan Kebudayaan Republik Indonesia sebagai sponsor dana pendidikan selama menjalani pendidikan pascasarjana

\section{DAFTAR PUSTAKA}

AOAC 2005. Official Methods of Analysis. Association of Official Analytical Chemists. Benjamin Franklin Station, Washington.

Afrila A. \& J. Firman. 2012. Keempukan pH dan aktivitas air (Aw) dendeng sapi pada berbagai konsentrasi ekstrak jahe (zingiber officinale roscoe) dan lama perendaman yang berbeda. Jurnal Ilmu dan Teknologi Hasil Ternak 7(2):6-12.

Akoh C.C. 2006. Handbook of Functional Lipids. Taylor \& Francis Group, LLC. Boca Raton.

Aminudin M. \& H. Inayati. 2009. Pengaruh lamanya penyimpanan terhadap pertumbuhan bakteri pada nasi yang dimasak di rice cooker dengan nasi yang dikukus. Mutiara Medika 9(2):18-22.

Aragao G.M.F., M.G. Corradini, \& M. Peleg. 2008. A phenomenological model of peroxide value's rise and fall during oxidation. J Am oil Chem Soc 85:11431153.

Arifin Z. 2008. Stabilitas Formalin dalam Daging Ayam selama Penyimpanan Seminar Nasional Teknologi Peternakan dan Veteriner.

[BSN] Badan Standarisasi Nasional. 2013. Standar Nasional Indonesia (SNI). SNI 2908:2013: Dendeng Sapi. Badan Standarisasi Nasional. Jakarta.

Dwiyanti G. 2014. Aktivitas antioksidan teh rosela (Hibiscus sabdariffa) selama penyimpanan pada suhu ruang. Proseding Seminar Nasional Sains dan Pendidikan Sains IX 21 Juni 2014, Salatiga. Hlm 536541.

[FDA] Food and Drug Administration. 2016. Bacterial Analitical manual, Edition 8 revision A. US.

Febrianti A., D. Gebi, \& S. Wiwi. 2014. Pengaruh suhu dan lama pemanasan terhadap aktivitas antioksidan dan total antosianin minuman sari ubi jalar ungu (Ipomea Batatas L.). Jurnal Sains dan Teknologi Kimia 5(2):85-95.

Flick G.J., G.P. Hong, \& G.M. Knobl. 1992. Lipid oxidation of seafood during storage. In: Allen J. St. Angelo, editor. Lipid Oxidation in Food. ACS Symposium Series 500. American Chemical Society, Washington, D.C. pp. 183-205

Gorris L.G.M. 2005. Food safety objective: an integral part of food chain management. Jurnal Food Control 16:801-809.

Health Protection Agency. 2009. Guidlines for Assesing the Microbiological Safety of Ready-to-Eat Foods.Health Protection Agency. London.

Ikhsan M., Muhsin, \& Patang. 2016. Pengaruh variasi suhu pengering terhadap mutu dendeng ikan lele dumbo (Clarias gariepinus). Jurnal Pendidikan Teknologi Pertanian 2:114-122.

Jahidin J.P. 2014. Aspek mikrobiologi dendeng asap dendeng daging yang berbeda pada 
pengasapan tempurung kelapa. Jurnal Ilmiah Ilmu-Ilmu Peternakan 17(1):39-43.

Marzaleni. 2005. Kajian Pengolahan Dendeng Batokok dengan Jarak Pengasapan Dingin Terhadap Kadar Lemak, ph Dan Uji Organoleptik. Fakultas Peternakan Universitas Andalas Padang. Padang.

Nagai R., M. Jinno, M. Inchihashi, H. Koyama, Y. Yamamoto \& Y. Yonai. 2012. Advanced glycation end product and their receptor as risk factors for aging. AntiAging Medicine 9(4):108-113

Nurwantoro, V.P. Bintoro, A.M. Legowo, A. Purnomoadi, L.D. Ambara, A. Prokoso, \& S. Mulyani. 2012. Nilai pH, kadar air, dan total escherichia coli daging sapi yang dimarinasi dalam jus bawang putih. Jurnal Aplikasi Teknologi Pangan. 1(2):20-22.

Okolie N.P. \& T.O. Okugbo. 2013. A comparative study of malondialdehyde contents of some meat and fish samples processed by different methods. J. Pharm. Sci. Innov. 2:26-29.

Purnomo H. 1997. Studi Tentang Stabilitas Protein Daging Kering dan Dendeng selama Penyimpanan. Laporan Penelitian. FP-Unibraw Press. Malang.

Pelczar M.J. \& E.C.S. Chan. 2008. Dasar-dasar Mikrobiologi. Jilid II. Hadioetomo R.S., Imas T., Tjitrosomo S.S., Angka S.L, penerjemah. UI Press. Jakarta.

Poluakan O.A., A.D. Henny, \& G.I. Frans. 2015. Mutu mikrobiologis bakso ikan yang direndam asap cair, dikemas vakum dipasteurisasi dan disimpan suhu dingin. Jurnal Media Hasil Teknologi Peternakan $3(2): 41-44$.

Resang A A. 1982. Ilmu Kesehatan Daging. FKH IPB. Bogor.

Rasyad N.V., R. Djalal, \& S.W. Aris. 2012. Pengaruh lama pemanggangan dalam microwave terhadap kualitas fisik steak daging ayam. Jurnal Ilmu dan Teknologi Hasil Ternak 7(1):6-11.

Saghir S., K.H. Wagner, \& I. Elmadfa. 2005. Lipid oxidation of beef fillets during braising with different cooking oils. Journal of Meat Science 71:440-445.

Salguero J.F., R. Gomez, \& M.A. Carmona. 1994. Water activity of spanish intermedite-moisture meat products. Meat Science 38:342-346.

Suharyanto. 2009. Aktivitas Air (Aw) dan warna dendeng daging giling terkait cara pencucian (leaching) dan jenis daging yang berbeda. Jurnal Sains Peternakan Indonesia 4(2):113-12-.

Suryati T., M. Astawan, H.N. Lioe, \& T. Wresdiyati. 2012. Curing ingredients, characteristics, total phenolic, and antioxidant activity of commercial Indonesian dried meat product (dendeng). Media Peternakan 35(2):111-116.

Suryati T., M. Astawan, H.N. Lioe, T. Wresdiyati, \& S. Usmiati. 2014. Nitrite residue and malonaldehyde reduction in dendeng-Indonesian dried meat-influenced by spices, curing methods and precooking preparation. Meat Sci. 96:1403-1408.

Soeparno. 2005. Ilmu dan Teknologi Daging. UGM Press. Yogyakarta.

Sorensen, G. \& S.S. Jorgensen. 1996. A critical examination of some experimental variables in the 2-thiobarbituric acid (TBA) test for lipid oxidation in meat products. Zeitschrift fur Lebensmittel Untersuchung und-forschung 202(3),205210.

Steel C.J., \& J.H. Torrie. 1995. Prinsip dan Prosedur Statistik. PT. Gramedia. Jakarta.

Thippareddi H. \& M. Sanchez. 2006. Thermal processing of meat product. In: Sun, D. W. Ed. Thermal Food Processing New Technologies and Quality Issue. Taylor \& Francis. New York. 